\title{
PERSPECTIVES ON RACE, GENDER AND POWER DIFFERENTIALS IN LIVED EXPERIENCES OF FAILED SUICIDE BOMBERS IN PAKISTAN
}

\author{
Munir Ahmad Zia Rao \\ $\mathrm{PhD}$ Scholar, \\ Institute of Social and Cultural Studies at University of the Punjab Lahore Pakistan \\ raomunir@gmail.com \\ Rubeena Zakar \\ Institute of Social and Cultural Studies at University of the Punjab Lahore Pakistan \\ rubeena499@googlemail.com
}

\begin{abstract}
The study documents lived experiences of failed suicide bombers in Pakistan. It describes the influence and impact of social structures like gender, geography race and ethnicity with reference to their experiencing of suicide bombing. The study also characterizes the power relations in their interactional contexts entailing in unquestioning submission and support to militant organizations. Owing to ideological charged conditions and overwhelming existence of terrorist organisation certain regions and ethnicities in Pakistan exhibit unusual inclination to suicide terrorism. The article also argues the strategic necessity and ideological under pining of feminizing suicide terrorism in Pakistan by terrorist outfits. Feminizing of suicide terrorism in Pakistan is driven by out of strategic and political expediency. Women in Pakistan are enlisted mostly by means of physical and emotional coercion, exploitation of familial ties and patriarchal influences. The lived experiences of the male and female suicide bombers gathered from in-depth interviews and secondary data delineate the factors and process of 'zombification'.
\end{abstract}

Keywords: Female suicide bombers, Suicide bombing, gender, race and ethnicity, terrorism, power.

\section{INTRODUCTION}

Suicide bombing is carried out for achieving pre-designed objective both at individual and organizational level wherein the subject lays down his or her life. It is not a recent phenomenon rather a recurring strategy employed by different militant outfits throughout human history. Sheehan (2014) held that on account of its lethality and effectiveness the worrisome trend is on rise in the modern era. The paper characterizes the experiences of the failed suicide bombers, based upon their perspectives and perception of the phenomenon with reference to geography, gender race and ethnicity and power. The objective is to investigate the impact and influence of social structures and power differentials in the social and militant settings of the failed suicide bombers. The findings offer an insight into the radicalization and indoctrination grounded in power differentials in the socio and militant setup. The findings endorse those tribal social settings, regions and ethnicity have a dominant role and presence in terrorist organisations and leading role in this extreme radicalization. The analysis of the Pakistani suicide bombers profiles illustrates that Khyber Pukhtun Khwa Province with 16\% of country population has contributed $58.6 \%$ of suicide bombers with Pushtoon ethnicity whereas the erstwhile Federally Administered Tribal Area with $03 \%$ of the total population has caused $28.6 \%$ of total suicide blasts. The paper also reflects the negligible role of feminine gender in terror suicidality as out of 15 in-depth interviews of failed suicide bombers there was only one female perpetrator. This insignificant display of feminist violent talent can be traced to hypermasculinity, and patriarchal influences embedded in social settings of Pakistan wherein perpetration of violence is deemed as male prerogative.

\section{METHODOLOGY}

Qualitative studies examining the lived experience of failed suicide bombers (particularly in Pakistan) are hard to come by and the purpose of this study is to examine their experiences in militant milieu of Pakistan. For this study, Phenomenology was used as methodology describing the suicide terrorism 
(attacks) with numerous situational experiences gathered from the personal lives of the subjects, for bringing forth the essence through their consciousness (Strieber and Carpenter,1975). It proffered direct investigation of suicide terrorism as consciously experienced phenomenon and the phenomenological design (description of experiences, epoche, phenomenological reduction, imaginative variation, and synthesis) allowed the researcher to examine their perceptions and experiences (Moustakas, 1994) The subjects of the research are suicide bombers who failed in carrying out the suicide attacks and were captured alive. They partake specific characteristics such as militant training, bottom-up socialization, exposure to militant ideology, radicalization, organizational affiliation, pro-choice in the act of self-annihilation and failure or aborting of mission at eleventh hour. Hence purposive sampling was employed (Patton,1990, 2002) and sample frame comprised 32 failed suicide bombers from all over Pakistan. Prior to conducting of their un-structured in-depth interviews, lasting around 55 to 60 minutes, permission and informed consents were sought along with meeting the ethical considerations. All questions were open-ended and were asked in a very polite and respectful language (in Urdu or Punjabi and Pushto). Most of the interviews were conducted in national language and in some cases assistants and translators were also involved. Since being a qualitative study, social reality was subjective, multiple, and diverse because of varying lived experiences of the subjects. It was treated as a contextual and socially developed phenomenon, consequently, inquirer (interviewer) and the inquired-into (interviewee) were interlocked in an interactive, participative, and collaborative process of data generation. During this entire process the researcher acted as stranger in the strange world through the technique of epoche to control the element of subjectivity in the research process.

\section{THEORETICAL FRAMEWORK}

The lived experiences of failed suicide bombers were analyzed and understood through the theoretical prism of Foucauldian construct of 'Power', Gramsci's outlook on 'Hegemony' and Althusser's concept of 'Ideology'. These outlooks appear recurrently in the lived experiences of the subjects and interchangeably punctuate their social and militant milieu. According to Foucauldian construct social relations are imbued with power, hence all social relations including governmental, personal, and familial relations are in fact power-relations. He further held that power is all pervasive, yet it is not per-se omnipresent as it stems from everywhere. Power is always directional and emphasizes on specific rather subjective results which largely hinge on the word selection (vocabulary) of the individual. Besides, labelling of the subjects is sine qua non for targeting and controlling their behaviors.

The qualitative data, when viewed through Gramsci's notion of 'hegemony' wherein power differentials and labelling make subjects submissive and the subjects take their surveillance for granted, depicted the subjects as being under the false consciousness, extemporaneously believed that power was exercised benevolently and beneficially. They held this situation as a means of group approval and social acceptance. Hence the construct of hegemony is well entrenched in meticulously designed system of sanctions and positive reinforcements. The research data also reveal that militants employ ideology as motivational force for furtherance and realization of their political objectives, whereas discipline is employed for eliciting the subjects' conforming behavior. Symbols and labels such as humiliation, glory, religion, sexuality, martyrdom, iconography, and honor are recurrently used in the discourses for the maintaining the hegemonic power structures. Foucauldian construct that knowledge is power, is analyzed in family and militant training camps environments wherein certain facts are created through selective quotes for upholding and supporting the organizational worldview. Consequently, the Power-knowledge discourse in their social settings does not mean power rather how certain knowledge is suppressed and other is shaped for validating the ideological goals. The deluded subjects are brought in harmonization with the ideological objectives by means of propaganda, publicity, and indoctrination. Despite the inherent discontent of system, the subjects develop the impression of happiness. Since ideologies are hegemonic and are deliberately spun to manipulate power, cultural supremacy, and the male domination, debilitating the subjects' vision and resultantly the things are taken for granted along with unconscious acceptance and support to the ideological interests of ruling class.

\section{RESULTS AND DISCUSSION}




\section{History of Female Suicide Terrorism}

Bari (2000) claimed that gender and patriarchy are unifying features of Pakistani society. Pakistani women are controlled through restraining behavioral codes, strict gender segregation, familial patterns and robust ideology pinning family honor to feminine virtue (Moghadam,1992). This sturdy "inside outside" dichotomy in the social fabric, restricting womenfolk within four walls of homes (Mumtaz \& Shaheed, 1987; Rai, Shah, \& Ayaz, 2007). Traditionally gender splits men into violent and women into non-violent roles and Pakistan women's roles in terrorism too was initially circumscribed within supporting non-violent spheres. Nevertheless, this division is not watertight as Iqbal (2015) observed that militant groups recruited women for a wide variety of roles ranging from static non-violent to a broader violent role. Nelly (2015) stated that a priori perception of Muslim women as suicide bombers is an anomaly and a misconception on part of policy makers. Cook (2005) held that women are enlisted by militants with greater degree of acceptance and approval. Nelly (2017) found that such a shift from nonviolent to violent role is triggered by religious ideology. Noor (2011) similarly opined that despite the cultural constraints militant organizations, on strategic grounds employ women in suicide terrorism. Winter (2015) traced the genesis of such changes in Pakistan back to the rise of Islamic State in Syria and Iraq in 2014.

According to Yoram (2006) globally male suicide bombers outnumber their female counterparts. Yoram (2006) claimed that during 1985- 2006 the female participation in suicide terrorism is recorded at 15\%. Lester, David, Yang and Lindsay (2004) observed Chechenia, Sirilanka and Turkey as outlier wherein female participation in suicide terrorism was overwhelming in contrast to their male counterparts. Banks (2019) claimed that women have been overlooked in terrorism studies while Weinberg and Eubank (2011) differed and claimed that they have been a part of terrorist movements both in support and frontline roles. Gentry and Sjoberg (2016) observed that in the recent "Religious Wave," women have performed manifold roles in violent insurgencies in Pakistan, India, Sri Lanka, Chechnya, Afghanistan, Palestine, Syria, Iraq, Yemen, and Kenya. Since 1980, in Pakistan suicide-bombings was a male dominated phenomenon and use of females was not a preferred strategy. Mahmood (2019) held that Pakistani and Indonesian women are thinly present in terrorist organisations may be taken as anomaly rather than a norm, hence they are featuring in international research and databases.

Pakistani Women's participation in suicide terrorism can be traced across the following timelines: during 1980s i.e., from Afghan to Kashmir jihad; formation of the Tehrik Taliban Pakistan and establishment of IS and its affiliated militant groups. During the 1980s, women extended emotional, financial, and logistical assistance to terrorist operators by strictly remaining within the familial domain. (Noor, Saba, \& Hussain, 2005). As noncombatant reserves, they assembled suicide vests, acted as spies, and raised fund (Mossarat,2018). TTP revolutionized their role as agile aides by deploying them as suicide bombers (Mohsin, 2013).

The suicide terrorism data from Pakistan displays following participatory trend. Out of research sample of 15 failed suicide bombers there was only one female perpetrator whereas 03 were in secondary data. The profiling data of Pakistani suicide bombers by Iqbal (2015) wherein 03 out of 80 bombers were females. During 2010-13, eight successful incidents of female suicide bombing took place in Pakistan. Out of the total 08 incidents, 03 were planned by LeJ and TTP each, whereas the remaining 02 incidents occurring in Peshawar and Bajur Agency went unclaimed. (Iqbal, 2015). Lashkar e Jhangvi is credited with pioneering of conscription and training of female suicide bombers. Besides, the Central Asian militant outfits like Islamic Movement of Uzbekistan (IMU) and the East Turkistan Islamic Movement (ETIM) also drafted and trained female suicide bombers for targeting high value individuals and installations in Pakistan. Jawad (2011) observed that these incidents clearly signify a departure from women's conventional roles. Similar views were opined by Zia (2011) that Islamic militants in Pakistan are embarking upon mobilizing women as suicide bombers as a part of their holy trope.

\section{Motivational Factors for Drawing Women in Suicide Terrorism}

According to Schweitzer (2004) Women's motivational factors to partake in such deadly attacks vary greatly and these should be viewed from individual and organizational standpoints. The analysis of primary data reveals that self-importance, martyrdom, spiritual obligation, heavenly rewards, and piety are the wages of suicide bombings. Researchers usually attribute women participation in suicide 
bombing to tactical and strategic advantages (Speckhard, 2008). Richardson (2005) opined that women are recruited based on 'strategic logic' imbued with tactical advantages entailing media attention and greater publicity. Similarly, Anne (2008) observed that female suicide bombings generate more shock value, media hype and the female bombers display greater maneuverability to bypass the stringent security measures. They can conceal explosives in clothing, can fake pregnancy and their deployment arouses less suspicion as security forces usually culturally overlook noncombatant populations (Zedilas, 2004). Besides tactical superiority, their participation in bombing squads also fairly swells the ranks of the militant organization (Turner, 2016). Fullmer et al., (2019) held terrorist outfits are increasingly using female suicide bombers as strategic choice. His findings claimed that out of 798 such attacks $15 \%$ were perpetrated by female suicide bombers. Since burqabombers generate greater psychological impact, TTP has resorted to veiled suicide bombing (Roggio $\&$ Weiss, 2015). Such strategic advantages take the better of the generalization which traditionally projects women as a noncombatant population (Cunningham, 2003).

\section{Lived Experiences of Pakistani Failed Female Suicide Bombers}

Since women lead complex lives hence it is difficult to find a universal explanation for their participation in terrorism particularly in the backdrop of Pakistan's militant milieu. The following cases characterize the pattern of logic defining failed female suicide bomber's roles within jihadist outfits, emanating from different sources such as ideological religious, logistical, social, and personal grounds. (Audery,2016).

Quite a lot of methods are drawn in by terrorist organizations to recruit women like physical and emotional coercion, conducting internet campaigns and pitching an ideological appeal (Sutten, 2009). Siddiqui (2012) the head of the criminal investigation team shared the disclosures of Hassan regarding indoctrination of his two nieces. He along with his wife, surreptitiously influenced them for suicide bombing mission in 2003. He arranged for their training as suicide bombers in the camp run by TTP in the conflict tribal area.

Sohana the minor girl, faced similar situation as she was abducted by terrorists and dropped near police check post armed with a suicide jacket. She was arrested before detonation and divulged to the news reporters, "They (terrorists) kept me in a house and told me to push the button (to detonate the suicide vest) when I reach near policemen." She said, "This morning, the women and men forced me to put on the heavy jacket and put me in the car again." "They put one suicide vest on me, but it did not fit. Then they put on another one," Sohana said. "I threw away the vest and started shouting (for help) as I came close to the check post and they (security forces) took me into custody," she further stated (Ali, 2011).

Weinberg and Eubank (2011) held that 'romantic and affectional ties' with partners and brothers who are active militants and involved in violence serve as motivational grounds. It is evident that in the case of Noreen Leghari the personal emotions played a vital role in facilitating the radicalization process. She was enlisted by male activists of IS as a potential suicide bomber. She allegedly married one of her enlisters and was supposed to carry out suicide bombing with her husband in Christian gatherings at Lahore (Gabol, 2017). Her initial investigation transpired that she willingly joined the self- styled Islamic State (IS) and had nurtured extremist tendencies while she was in contact with terrorists via social media. She informed her family through social media that she had reached the land of 'Khilafat' [Caliphate]. Contrarily, Prof. Leghari, her father denied having ever noticed extremist tendencies in her and held that she was kidnapped. Noreen hardly displayed her extremist activities and penchant for militancy and violence in the medical university campus. In her case alleged romantic relationships and male dominance remained a vital factor along with the ideology and radicalization. Similar situation was faced by Meena Gul a 12-year-old would be suicide bomber girl was apprehended by law enforcement agencies divulged about Farida another captive girl who was the granddaughter of Sufi Muhammad, the spiritual head of Tehreek-e Nefaz-e Shariat-e Muhammadi.

O'Connor and Alisa (2007) held that growing number of women participants in terrorism points to strategic necessity on the part of terrorist organizations. Cunningham (2003) suggests that 'contextual pressures create a convergence between female terrorist, militant leaders and social set up that eventually upsurges women's participation in terrorism. Stern (2003) employs the social contagion theory to deliberate how cultures of violence can be transmittable and give a fillip to more 
women for joining violence. Contrastingly, Sutten (2009) argues that most often personal motivational factors for women are byproducts of the environment or culture wherein they move.

The above discussed lived experiences highlight coercion and victimization of female suicide bombers in their respective social settings. Similar views are proffered by Bhatia and Knight (2011) that women are victimized in highly patriarchal society and by militant organizations. They further pointed out that several interconnected factors such as disturbed societies, individual inspirations and the presence of extremist organizations are accountable for women's choice for partaking in terroristic activities. In the militant context of above-mentioned female suicide bombers, they are both victims and perpetrators of violence (Bhatia, Vandana, \& Knight, 2011). Every so often, they are victims of patriarchal set up which usually downgrade women to the background. Occasionally women are intoxicated and coerced forced to carry out the suicide bombings and this process is dubbed as 'zombification' (Groscop, 2004). The lived experiences of the above stated failed female suicide bombers truly characterize this process as the influence and connection between coercion, intoxication, indoctrination, and 'Zombification' are major is a contributor of their involvement in the suicide terrorism.

\section{Race and Ethnicity}

Most of the militant training camps in Pakistan were located in Federally Administered Tribal Areas (FATA) and Malakand Division (Lalwani, 2010). These distant and far-off places were ideologically charged and radicalized hence served as natural recruiting grounds (Waraich, 2010). Furthermore, the dwindling social structure and little social mobility left the local youth with no option but to join militants.

In training camps, 90\% of suicide bombers were ethnically Pashtun (Tajak, 2010). The unpublished report by Pakistan's Special Investigation Group claimed that $70 \%$ of suicide attacks were carried out by Mehsud tribe. Ishaq the would-be suicide bomber reckoned the ideologically charged atmosphere and prevalence of militant camps as its main reasons. Tribal in general and Mehsud exhibited greater degree of admiration and social acceptance of suicide bombings. Extolling the valor and social acceptance of the suicide bombers entailed in more incitement to youth to emulate holy deaths. Pashtu was the working language of camps and translators for non-Pushtoon trainees were arranged (Tajik, 2010). An anonymous failed suicide bomber shared the same, "There are too many-almost entire Miran Shah is there" (Safi, 2009). Shakir another suicide bomber expressed that camp was thronged by people from FATA (A. Shakir, personal communication12 ${ }^{\text {th }}$ Feburay,2020). Furthermore, the analysis of profiling of suicide bombers by Iqbal (2015) establishes that KP Province with $16 \%$ of Pakistan's population has contributed $58.6 \%$ of suicide bombers with Pushtoon ethnicity. However, what used to be called FATA with $03 \%$ share of Pakistan's population contributed up to $28.6 \%$ in suicide bombings.

\section{Power Differentials}

The familial and militant camps settings discouraged the subjects from questioning which is sine qua non for ascertaining the cogency and reliability of proffered ideas. It paved the way for the initial phase of brainwashing assuming the form of emotional-religious wheedling by charismatic rather significantly dominant individuals. (4. 9/11 Commission Report, pp. 165, 233.) Based on the power differentials, the influence of "inspirational" individuals multiplies manifold particularly when juxtaposed with peer and normative pressures.

When questioned about challenging IS ideology, Lagnoree the female suicide bomber acknowledged her incapacity, "May be, this in near future in some - since, I was alone and scared to certain extent of that thing" (Lagnoree, personal communication, 2018). Shakir, a minor failed suicide bomber when inquired whether he ever thought of asking his trainers to go to paradise directly by way of suicide bombing? "N-no, no. It never crossed my mind", he frightfully replied (A. Shakir, personal communication $12^{\text {th }}$ Feburay,2020). Despite being in romantic relations with her enlister Ali, Lagnoree had very formal organizational relations with him. She said, "Commander he was - when they ordered, then, [we] had to comply with. It looked — as if — and they said dear — even that much was not done - between us - I mean - I thought that somewhat more — acting like — as I mean, saying like this 'dear' will be done — not an issue you sit here". (Lagnoree, personal communication, 
2018). She took him as an opinion leader, a man from a field with superior field knowledge and patronizing attitude. Hence, she did not dare to contradict and question.

The militants' got control over the body of minors through physical force and that of cognitive process through intoxication. The power differential is evident from their conversation regrading strategic issues on suicide bombing. Abdussalman while sharing pre-enlistment discussion said, "If I told anyone, he would chop my head off, and I was so frightened that I felt faded" (A. Salman, personal communication, $26^{\text {th }}$ October,2010). Fazal e Khalil 12 years old would-be suicide bomber shared his experience, "When I used to give some of information — trainings — after that they used to laugh" (F. Khalil, Personal communication, February 12, 2020). Kahlil's Trainers used to maintain a fair distance and advised, "Do not come here as we are elders and when elders are talking something, you are not supposed to sit here". I was not allowed to criticize, "Whatever you are told, you are supposed to act upon." I was not allowed to give my suggestion, "We are much better than you that is why you are with us[sic]. While commenting upon his social context and settings he admitted, "There was no ideological conflict - there was within the mind, as an attitude but that could not appear as behavior". He further added that in tribal regions, "Elders are supposed to tell, and you are supposed to accept[sic]. There is "no" yes (??) there is no "No" in that culture. After sometimes you are addicted, and the other persons' ideas are imposed on you". (F. Khalil, Personal communication, 12th February 2020).

The militant instructor ordered Khaliq, a barely 7 years kidnapped minor, "Blast", "They are infidels". They did not teach. They (target) are infidels". (K. Khaliq, personal communication, $12^{\text {th }}$ February 2020). A rather mature minded failed suicide bomber expressed in a televised interview that orders by Amir are mandatory and to be carried out without questioning and observations. Another abducted minor said, "I asked them initially certain questions, but they thrashed me so severely that I could not repeat such questions in the future". Fazle Khaliq said that in tribal regions, "Elders are supposed to tell, and you are supposed to accept[sic]. There is "no" yes (??) there is no "No" in that culture. After sometimes you are addicted and the other persons' ideas are imposed on you" (K. Khaliq, personal communication, $12^{\text {th }}$ February 2020).

\section{DISCUSSION}

Customarily, militant outfits employ violence against women as a propaganda tool to voice their contempt for western values. However, with their switching to female bombing in Pakistan has defied their conventional stance. Given the overall patriarchal discourse both in settled and tribal communities, the female suicide bombings cannot be taken as a sign of their free consent and selfrealization. Lagnoree's apparent free choice to join militant outfits and her notion of freedom fizzles out in the face of male supremacy in militant and non-militant settings. During her stay with the terrorists, she realized that her independence and free choice in decision making was nothing but superficial and transient.

Most adolescent and minor failed suicide bombers hailed from erstwhile FATA region and were forcibly enlisted by TTP to embark upon the holy suicide mission. They were taken from their families as a policy of forced conscription by militants. Their free consent was substituted by physical force and use of remote-controlled suicide vests. Whereas in cases of resistance, drugs were administered too for controlling their conscious minds and subsequent indoctrination. Consequently, suicide vest detonation process was controlled by the handlers to counter any on-spot defections. Hence, this makeshift terrorism strategy does not necessitate reliance on prolonged indoctrination process. This clearly specifies the factors other than radicalization such as force, coercion, familial and peer pressures intertwined with religious and emotional exploitations of subjects for embarking upon the alleged holy self-annihilation mission.

Sohana Javed was abducted and administered drugs for carrying out a suicide blast on police check post (Ali, 2011). Gul Hassan, the uncle of Arifa and Saba initially persuaded his nieces for suicide becoming and managed their training at TTP camp administered by Fazal Ullah (Siddiqui, 2012). Meena Gull, another minor girl was influenced and persuaded by his brother, a local Taliban commander to become suicide bomber under impression that it was beneficial both for herself and the family. Frida, another girl who escaped with her from TTP camp, was the granddaughter of the chief of TNSM (Tribune, 2009). These incidents clearly establish how family institutions and social control mechanisms are manipulated by elderlies in a culturally conservative society. Noor (2011) similarly 
held that cultural pressures, control mechanisms, normative and disciplinary forces are driving the subjects into false consciousness to serve the organizational purposes. Besides, in the case of Lagnoree personal romantic relations played a vital role in influencing the decision-making process. The medical university student was lured and conscripted by male IS activists and she was influenced, in a communicative and social setting dominated by male members to carry out suicide bombing (Ali, 2011).

\section{CONCLUSION}

Social facts and structures such as existence of terrorist organizations, indoctrinated communities, social acceptance and approval of militancy, culture of violence and militancy contribute to the making of suicide bombers. Indoctrinated geographies and radicalized ethnicities which are ideologically charged along with the relentless militant propaganda and control of militant organizations, have become bastion of suicide terrorism. Khyber Pukhtunkhwa Province with 16\% of Pakistan's population has contributed 58.6\% of suicide bombers with Pushtoon ethnicity. Particularly, the former Federally Administered Tribal Area with 03\% of the national population has caused 28.6 $\%$ of suicide bombings. According to research data majority of failed suicide bombers are preadolescent, ethnically Pushtoon and come from closed tribal societies. Structural factors are employed by terrorist operators to manipulate power structures which debilitate suicide bombers' vision and thereby entailing in unthinking - absolute submission. Militant trainers, religious effigies, and family elders, socially and intellectually dominate the subjects through conventional reverence associated with their statures in the social context wherein questioning is an audacious act. The resistant subjects were administered drugs to control their free will and conscious mind. Their consent was manipulated through deceit, physical overpowering, and subsequent use of remote-controlled technology. Strategic necessity and advantages lead to the feminizing of suicide terrorism by the terrorist outfits. Feminizing of suicide terrorism in Pakistan is driven by out of strategic and political expediency. Pakistani Women are enlisted mostly by means of physical and emotional coercion, exploitation of familial ties and patriarchal influences. Sometimes women are drugged, kidnapped, and exploited through romantic love and family affection. The interplay of such factors entails in what Russian call 'zombification 'and are leading contributors of feminizing suicide terrorism in Pakistan.

\section{REFERENCES}

Ahmed, I., (2011). Another female suicide bomber strikes in Pakistan. Taliban desperation? The Christian Science Monitor. Retrieved from https://www.csmonitor.com/

Alexander, A. (2016). Cruel intentions: Female jihadists in America. Program on Extremism.

Ali, M. (2011). Police detain 9-year-old girl with suicide vest https://tribune.com.pk/story/192647/suicide-bomber-surrenders-herself-to-security-officials

Al-Tamimi, A. (2017). ISIS Female Suicide Bombers Are No Myth. Foreign Affairs, 91-98.

Banks, C. (2019). Introduction: Women, gender, and terrorism: Gendering terrorism.

Bari, F., \& Pal, M. S. (2000). Country briefing paper: Women in Pakistan. Asian Development Bank Programs Department and Office of Environment and Social Development, 8.

Bhatia, V., \& Knight, W. A. (2011). Female suicide terrorism in South Asia: Comparing the Tamil separatists and Kashmir insurgents. South Asian Survey, 18(1), 7-26.

Bloom, M. (2012). Bombshell: women and terrorism. University of Pennsylvania Press.

Catherine Belsey, C., (2001). Critical Practice. Routledge, London.

Cook, D. (2005). Women fighting in Jihad? Studies in Conflict \& Terrorism, 28(5), 375-384.

Cunningham, K. J. (2003). Cross-regional trends in female terrorism. Studies in conflict and terrorism, 26(3), 171-195.

Drake, C. J. (1998). The role of ideology in terrorists' target selection. Terrorism and Political Violence, 10(2), 53-85.

Fullmer, N., Mizrahi, S. L., \& Tomsich, E. (2019). The Lethality of Female Suicide Bombers. Women \& Criminal Justice, 29(4-5), 266-282.

Gentry, C. E., \& Sjoberg, L. (2016). Female terrorism and militancy. The Routledge Handbook on Critical Terrorism Studies. 
Groskop, V. (2004). “Chechnya's Deadly 'black Widows" New Statesman 13.4704 (2004): 32-33.

Hayat, N., \& Juliana, A. W. (2016). A Comparative Analysis of Pakistani English Newspaper Editorials: The Case of Taliban's Attack on Malala Yousafzai. Pertanika Journal of Social Sciences \& Humanities, 24(3).

How Many More Suicide Bombers? (July 11, 2003). What the Papers Say (Russia) sec. Shorts, p. 1, 6, database on-line; available from Lexis-Nexis; accessed on December 6, 2020.

Kimhi, S. (2007). Yoram Schweitzer (Ed.): Female Suicide Bombers: Dying for Equality? (Tel Aviv University: Jaffee Center for Strategic Studies (JCSS), Memorandum No. 84., 2006).

Lahoud, N. (2014). The neglected sex: The Jihadis' exclusion of women from Jihad. Terrorism and Political Violence, 26(5), 780-802.

---(2017). Can women be soldiers of the Islamic state?. Survival, 59(1), 61-78.

Lalwani, S. (2010). The Pakistan Military's Adaptation to Counterinsurgency in 2009. CTC Sentinel, 3(1), 9-13.

Lester, D., Yang, B., \& Lindsay, M. (2004). Suicide bombers: Are psychological profiles possible?. Studies in Conflict \& Terrorism, 27(4), 283-295.

Louise, S. (2007). What Terrorists Want: Understanding the Enemy and Containing the Threat. Penguin Random House Trade.

Lukacs, G. (1967). History \& Class Consciousness. London: Merlin Press. ISBN 978-0850361971

Mahmood, S. (2019). Negating Stereotypes: Women, Gender, and Terrorism in Indonesia and Pakistan. Perspectives on the Future of Women, Gender \& Violent Extremism. Washington, DC: The George Washington University, 11-20.

Mia, B. (2011). Bombshell: Women and Terrorism. University of Pennsylvania Press.

Moghadam, V. M. (1992). Patriarchy and the politics of gender in modernising societies: Iran, Pakistan and Afghanistan. International Sociology, 7(1), 35-53.

Mohsin, A. (2013). The Rise of Radio Mullah. Foreign Policy. Retrieved from https://foreignpolicy.com/2013/12/23/the-rise-ofradio-mullah/.

Noor, S. (2011). Women Suicide Bombers: An Emerging Security Challenge for Pakistan. Counter Terrorist Trends and Analyses, 3(11), 1-3.

Noor, S., \& Hussain, D., (2005). Women and Radicalisation: An Empirical Study. Pakistan Institute of Peace Studies. Retrieved from https://pakpips.com/web/wpcontent/uploads/2017/11/205.pdf.

O'rourke, L. A. (2009). What's special about female suicide terrorism?. Security Studies, 18(4), 681718.

Pakistan: United Nations Development Programme. Retrieved from http://undp.org.pk/images/

Police department, Pakistan Police interrogation report, (June, 2008) subject Mir Janan, Islamabad

------- (June, 2008) subject Aitezaz Shah, Dera Ismail Khan.

-------- (June, 2009), subject Hasnain Gul (also known as Ali Punjabi), Rawalpindi, Pakistan (June,2008). subject Ishaq Mehsud.,

Qadeem, M. (2018). Engendering extremism: women preventing and countering violent extremism in Pakistan.

Rai, S., Shah, N., \& Ayaz, A. (2007). Achieving gender equality in public offices in Pakistan. Islamabad, Pakistan: United Nations Development Program.

Rosenbaum, W. A. (1975). Political Culture London: Nelson, 1975, p. 120

Sara, M. (2017). Pakistan's Women Jihadis. The Diplomat. https://thediplomat.com/2017/04/pakistanswomen-jihadis/.

Schweitzer, Y. (2003). A fundamental change in tactics. Washington Post, 19, 3.

Shapiro, L. R., \& Maras, M. H. (2019). Women's radicalization to religious terrorism: An examination of ISIS cases in the United States. Studies in Conflict \& Terrorism, 42(1-2), 88119.

Siddiqui, A., Head of Special Investigation Group, Federal Investigation Agency of Pakistan, research interview, Islamabad, September 18, 2012.

Speckhard, A. (2008). The emergence of female suicide terrorists. Studies in Conflict \& Terrorism, 31(11), 995-1023.

Speckhard, A. (2008). The emergence of female suicide terrorists. Studies in Conflict \& Terrorism, 31(11), 995-1023. 
Stack-O'Connor, A. (2007). Picked last: Women and terrorism. National Defense Univ Washington Dc Inst for National Strategic Studies.

Stern, J. (2003, August). Terror in the Name of God. New York: Ecco.

Sutten, M. L. (2009). The rising importance of women in terrorism and the need to reform counterterrorism strategy. Army Command and General Staff Coll Fort Leavenworth Ks School of Advanced Military Studies.

Tajak, S. H. (2010). Insight into a Suicide Bomber Training Camp in Waziristan volume 3, issue 3 https://www.ctc.usma.edu/insight-into-a-suicide-bomber-training-camp-in-waziristan/

Unknown reporter, (2009). Meena Gull failed suicide bomber. https://www.youtube.com/user/theexpresstribune

Waraich, O. (2009). Taliban running school for suicide bombers. The Independent, 29.

Watching Her Go from a Doll to a Rock to a Bomb (January 30, 2002) Los Angeles Times (California), sec. California Metro, database on-line; available from Lexis-Nexis; accessed on $6^{\text {th }}$ December 2020.

Weinberg, L., \& Eubank, W. (2011). Women's involvement in terrorism. Gender Issues, 28(1), 22-49.

Winter, C. (2015). Women of the Islamic State: A manifesto on women by the Al-Khanssaa Brigade. Quilliam Foundation, 18.

Yasmeen, S. (2016). Pakistan, Muslim Womanhood and Social Jihad: Narratives of Umm Abd Muneeb. Islam and Christian-Muslim Relations, 27(3), 251-265.

Zedalis, D. D. (2004). Female suicide bombers. Carlisle, PA: Strategic Studies Institute. US Army.

Zia, A. S. (2011). Female suicide bombings in Pakistan-what's in it for women. Retrieved September, 12, 2017. 